\title{
Echocardiographic findings in kidney transplanted Type 1 (insulin-dependent) diabetic patients with and without a pancreas transplant
}

\author{
G. Nyberg ${ }^{1}$, O. Bech-Hanssen ${ }^{2}$, M. Olausson ${ }^{1}$ and I. Wallentin ${ }^{2}$ \\ ${ }^{1}$ Transplant Unit and ${ }^{2}$ Department of Clinical Physiology, Sahlgrenska Hospital, Göteborg, Sweden
}

Summary, Echocardiography with Doppler recordings was carried out in 14 Type 1 (insulin-dependent) diabetic recipients of pancreas and kidney transplants and in 14 Type 1 diabetic kidney transplanted control patients, matched for age, sex, duration of diabetes, extent of other late complications, time since transplantation, dose of prednisolone, and renal function. $\mathrm{HbA}_{1 \mathrm{c}}$ was $5.5 \pm 0.6 \mathrm{vs}$ $8.7 \pm 1.4 \%$ (pancreas transplanted vs kidney only). Both groups had a slight increase in interventricular septum thickness. Left ventricular mass was equal. The ejection fraction as a measure of systolic function was normal and equal, $0.71 \pm 0.05$ vs $0.69 \pm 0.07$. Diastolic function was also equal in two out of three parameters, isovolumic relaxation time and deceleration time. The $\mathrm{A} / \mathrm{E}$ ratio, however, tended to be lower in the pancreas transplanted group, $0.94 \pm 0.20$ vs $1.06 \pm 0.18(\mathrm{p}=0.04)$. This indicates more frequent occurrence of impaired diastolic filling in the recipients of kidney only. Follow-up will show whether diastolic dysfunction increases and may be related to the increased cardiovascular mortality in kidney transplanted Type 1 diabetic patients.

Key words: Type 1 diabetes - Pancreas transplantation Echocardiography - Diastolic function

\section{Introduction}

Mortality from cardiovascular disease is high in Type 1 (insulin-dependent) diabetic patients with nephropathy (Krolewski et al. 1987; Borch-Johnsen and Kreiner 1987; Ritz et al. 1985), also following renal transplantation (Frei et al, 1989). A reduction of the mortality has been reported in patients who received a simultaneous pancreas and kidney transplant (Brekke et al 1990; Abendroth et al 1989). The mechanism for such an effect is unclear. Sudden death may be related to arrhythmia or to impaired myocardial function (Ritz et al. 1987). We have assessed left ventricular dimensions and function by echocardiography in kidney transplanted
Type 1 diabetic patients with or without a functioning pancreas transplant.

\section{Subjects and methods}

Patients. Fourteen pancreas and kidney transplanted Type 1 diabetic patients and 14 kidney transplanted Type 1 diabetic patients were investigated. The kidney transplanted patients were selected to match the pancreas transplanted patients with regard to age, sex, time since onset of diabetes and extent of diabetic complications. Thus, each kidney transplanted patient had been judged to be eligible for pancreas transplantation. The reason why only a kidney was transplanted was the preference of a living related kidney donor in five cases, and the patient's decision in nine cases.

The pancreas recipients had been transplanted according to a uniform technique, using the segmental pancreas and with exocrine drainage to the urinary bladder (Frisk et al. 1987). Eleven transplantations were simultaneous pancreas and kidney transplantations while three were pancreas after kidney. No patient received exogenous insulin following transplantation.

The maintenance immunosuppressive protocol was triple therapy in both groups of patients, i. e. a combination of cyclosporine A, prednisolone and azathioprine, with the exception of one recipient of a kidney from an HLA identical sibling who did not take cyclosporine. Blood pressure was spontaneously normal in only four patients but the same levels were reached using antihypertensive treatment in the others. This required one to four antihypertensive drugs per patient.

Detailed clinical data are presented in Table 1.

Transplant function. Glycaemic control was estimated as glycated haemoglobin $\mathrm{A}_{1 \mathrm{c}}\left(\mathrm{HbA}_{1 \mathrm{c}}\right)$ which was analysed with an HPLC technique using ion exchange chromatography on Mono $S$ (Pharmacia Fine Chemicals AB, Uppsala, Sweden). The pancreas transplanted patients had a lower mean value than the recipients of kidney only, but it was above the upper normal range which is $5.2 \%$.

Renal function was measured as serum creatinine as well as plasma clearance of ${ }^{51}$ Crom EDTA after single bolus injection. There were no significant differences between the groups with either technique.

Echocardiography. The echocardiographic investigation included two-dimensional (2-D), M-mode, colour-, pulsed-, and continuous wave Doppler. We used an Acuson 128 with 2 and $3 \mathrm{MHz}$ imaging transducers and a $2.25 \mathrm{MHz}$ non-imaging continuous wave Doppler transducer. Echocardiography was performed with the patient in a left lateral position. The 2-D examination included the following views: parastemal long and short axis, apical long axis, four-chamber and two-chamber view. The control setting of 
our echocardiograph aimed at defining the endocardium of the left ventricle. The mean of three cardiac cycles was used.

M-mode signals for various dimension measurements were recorded from a 2-D short axis view. M-mode measurements of left ventricular end diastolic diameter as well as the thickness of the interventricular septum and the posterior wall were done at the peak of the $\mathrm{R}$-wave in the ECG (Knutsen et al. 1989). Ejection fraction was calculated applying Teichholtz's equation for volume measurements (Teichholtz et al. 1976).

For left ventricular mass calculation, we applied an algorithm derived by integration from the formula of a truncated ellipsoid (Byrd et al. 1989). Two views are required: one parastemal short axis view and one apical four- or two-chamber view.

The isovolumic relaxation period was calculated from M-mode recording of aortic valve closure and the mitral leaflet opening. Mitral inflow velocites i.e. the velocity deceleration time in the early filling phase, the peak flow velocity in early filling $(E)$ and the peak flow velocity in atrial systole (A) were measured. The upper normal range for the ratio $\mathrm{A} / \mathrm{E}$ was set at 1.0 .

Statistical analys. Results are given as mean \pm S.D., unless otherwise stated. Differences between the groups were calculated using the Student's t-test.

Table 1. Clinical data for kidney transplanted Type 1 (insulin-dependent) diabetic patients with or without a pancreas transplant. Values are mean \pm S.D. unless otherwise stated.

\begin{tabular}{|c|c|c|}
\hline & $\begin{array}{l}\text { Pancreas } \\
\text { transplanted }\end{array}$ & $\begin{array}{l}\text { Kidney } \\
\text { only }\end{array}$ \\
\hline Number of patients & 14 & 14 \\
\hline Males/females & $10 / 4$ & $10 / 4$ \\
\hline Age, years & $39 \pm 6.9$ & $39 \pm 4.9$ \\
\hline $\begin{array}{l}\text { Time since diabetes onset } \\
\text { years, median }\end{array}$ & 25 & 26 \\
\hline range & $19-33$ & $21-32$ \\
\hline $\begin{array}{l}\text { Time since transplantation } \\
\text { years, median }\end{array}$ & 2 & 2 \\
\hline $\begin{array}{l}\text { range } \\
\text { redinedia }\end{array}$ & $1-4$ & $0.5-4.5$ \\
\hline $\begin{array}{l}\text { Dose of prednisolone } \\
\mathrm{mg} / \mathrm{day}\end{array}$ & $7.5 \pm 1.0$ & $7.0 \pm 2.0$ \\
\hline $\begin{array}{l}\text { Serum creatinine } \\
\mu \mathrm{mol} / 1\end{array}$ & $125 \pm 34$ & $148 \pm 48$ \\
\hline $\begin{array}{l}{ }^{51} \text { Cr EDTA clearance } \\
\mathrm{ml} / \mathrm{min} \text { per } 1.73 \mathrm{~m}^{2}\end{array}$ & $58 \pm 17$ & $49+17$ \\
\hline $\mathrm{HbA}_{1 \mathrm{c}}, \%$ & $5.5 \pm 0.6$ & $8.7 \pm 1.4$ \\
\hline $\begin{array}{l}\text { Diastolic blood pressure } \\
\mathrm{mmHg}\end{array}$ & $85 \pm 11$ & $81 \pm 14$ \\
\hline Maximal working capacity, watt & $119 \pm 35$ & $118 \pm 31$ \\
\hline
\end{tabular}

\section{Results}

The results of the echocardiographic investigations in both groups of patients are presented in Table 2 . A slight and similar increase in interventricular septal thickness was recorded in both groups and left ventricular mass did not differ. Left ventricular systolic function, measured as the ejection fraction, was normal in both groups. Diastolic function expressed as isovolumic relaxation time and deceleration time did not differ, whereas the $\mathrm{A} / \mathrm{E}$ ratio tended to be higher in the kidney transplanted group $(p=0.04)$. Eight of the 14 kidney transplanted patients had values above the upper normal range vs 4 of the 14 pancreas transplanted patients.
Table 2. Echocardiographic findings in kidney transplanted Type 1 (insulin-dependent) diabetic patients with or without a pancreas transplant. Values are mean \pm S.D.

\begin{tabular}{lcc}
\hline & $\begin{array}{c}\text { Pancreas } \\
\text { transplanted }\end{array}$ & $\begin{array}{c}\text { Kidney } \\
\text { only }\end{array}$ \\
\hline $\begin{array}{l}\text { Number of patients } \\
\text { Interventricular septum } \\
\text { thickness, mm }\end{array}$ & $12 \pm 2$ & 14 \\
$\begin{array}{l}\text { Posterior left ventricular } \\
\text { wall, mm }\end{array}$ & $11 \pm 2$ & $13 \pm 3$ \\
$\begin{array}{l}\text { Left ventricular mass, g } \\
\text { Ejection fraction }\end{array}$ & $156 \pm 40$ & $10 \pm 1$ \\
$\begin{array}{l}\text { Isovolumic relaxation } \\
\text { time, ms }\end{array}$ & $0.71 \pm 0.05$ & $166 \pm 36$ \\
$\begin{array}{l}\text { Deceleration time, ms } \\
\text { A/E ratio }\end{array}$ & $68.6 \pm 12.4$ & $0.69 \pm 0.07$ \\
& $188 \pm 57$ & $62.9 \pm 10.1$ \\
& $0.94 \pm 0.20$ & $187 \pm 50$ \\
& & $1.06 \pm 0.18$ \\
\hline
\end{tabular}

$\mathrm{A} / \mathrm{E}$ ratio $=$ the ratio between peak mitral flow velocity in atrial systole (A) and during early filling (E).

\section{Discussion}

In most respects, the results of the echocardiographic investigations did not differ between the groups. The careful matching was a prerequisite for such a result as, at least in our institution, randomly selected kidney transplanted diabetic patients would have had more advanced complications also affecting cardiac function.

Filling disorders of the left ventricle may give various different mitral flow velocity patterns (Appleton et al. 1988). In diabetic patients with renal insufficiency the most common pattern is one with prolongation of isovolumic relaxation time and reduced early passive filling. The consequence is a dominance of the filling caused by atrial contraction i.e. an increase in $\mathrm{A} / \mathrm{E}$ ratio. Other mitral flow velocity patterns with normal or low $\mathrm{A} / \mathrm{E}$ ratio may be seen when filling pressures are high. Our study subjects, however, have a normal systolic function and are not expected to have increased filling pressures. Therefore, an increased A/E ratio is a reliable expression of diastolic dysfunction.

Hypertension, fluid overload, and ischaemic heart disease, which are frequently seen in these patients, may all cause impaired diastolic function with high $\mathrm{A} / \mathrm{E}$ ratio. This means that the mitral flow pattern does not reveal the contribution of each factor. There is no reason to believe that the two well-matched groups of patients studied here differed with respect to these factors.

The slight hypertrophy of the left ventricular wall which was recorded is probably an effect of longstanding hypertension and periods of fluid overload prior to the renal transplantation (Thuesen et al. 1988; Hüting et al. 1988; Sampson et al. 1990). In spite of this almost inevitable experience in this disease, left ventricular systolic function was well preserved in all patients. In fact, left ventricular systolic and diastolic 
function have been reported to improve and the left ventricular mass to be reduced following kidney transplantation in Type 1 diabetic patients (Larsson et al. 1986). Much of what was previously considered to be primary, early or late, effects of the diabetic state on cardiac function has thus been shown to be consequences of hypertension and renal insufficiency.

Diabetes per se may also cause an increased A/E ratio (Paillole et al. 1989). Our findings suggest that left ventricular diastolic filling might be improved by pancreas transplantation. Follow-up will show whether the difference between the groups will increase with time and whether this abnormality has prognostic implications.

\section{References}

Abendroth D, Illner W-D, Landgraf R, Land W (1990) A different clinical course of IDDM patients after simultaneous pancreas and kidney transplantation and kidney grafting alone. Transpl Proc 22:1579

Appleton CP, Hatle LK, Popp RL (1988) Relations of transmitral velocity patterns to left ventricular diastolic function: new igraphic study. J Am Coll Cardiol 12:426-440

Borch-Johnsen K, Kreiner S (1987) Proteinuria: value as a predictor of cardiovascular mortality in insulin-dependent diabetes mellitus. BMJ 294:1651-1654

Brekke IB, Holdaas H, Albrechtsen D, Fauchald P, Flatmark A (1990) Combined pancreatic and renal transplantation: Improved survival of uremic diabetic patients and renal grafts. Transpl Proc $22: 1580$

Byrd BF, Finkbeiner W, Bouchard A, Silverman NH, Schiller NB (1989) Accuracy and reproducibility of clinically aquired twodimentional mass measurements. Am Heart J 117:133-137

Frei U, Schorn T, Bunzendahl H (1989) Kidney transplantation in diabetic nephropathy In: Heidland A, Koch KM, Heidbreder E (eds): Diabetes and the kidney. Contrib Nephrol, Basel, Karger 73:199-208
Frisk B, Hedman L, Brynger H (1987) Pancreaticocystostomy with a two-layer anastomosis technique in human segmental pancreas transplantation. Transplantation 44:836-837

Hüting J, Kramer W, Schütterle G, Wizemann V (1988) Analysis of left-ventricular changes associated with chronic hemodialysis. A noninvasive follow-up study. Nephron 49:284-290

Knutsen KM, Stugaard M, Michelsen S, Otterstad JE (1989) Mmode echocardiographic findings in apparently healthy, nonathletic Norwegians aged 20-70 years. J Int Med 225:111-115

Krolewski AS, Kosinski EJ, Warram JH, Leland OS, Busick EJ, Asmal AC, Rand LI, Christlieb AR, Bradley RF, Kahn CR (1987) Magnitude and determinants of coronary artery disease in juvenile-onset, insulin-dependent diabetes mellitus. Am $\mathbf{J}$ Cardiol 59:750-755

Larsson O, Attman P-O, Beckman-Suurküla M, Wallentin I, Wikstrand $J$ (1986) Left ventricular function before and after kidney transplantation. A prospective study in patients with juvenile-onset diabetes mellitus. Eur Heart J 7:779-791

Paillole C, Dahan M, Paycha F, Solal AC, Passa P, Gourgon R (1989) Prevalence and significance of left ventricular filling abnormalities determined by doppler echocardiography in young type I (insulin-dependent) diabetic patients. Am J Cardiol 64:1010-1016

Ritz E, Strumpf C, Katz F, Wing AJ, Quellhorst E (1985) Hypertension and cardiovascular risk factors in haemodialyzed diabetic patients. Hypertension 7 (Suppl II): II-118-II-124

Ritz E, Kuffmann, Rambausek M, Mall G, Schmidli M (1987) Dialysis hypotension - is it related to diastolic left ventricular malfunction? Nephrol Dial Transpl 2:293-297

Sampson MJ, Chambers JB, Sprigings DC, Drury PL (1990) Intraventricular septal hypertrophy in Type 1 diabetic patients with microalbuminuria or early proteinuria. Diab Med 7:126131

Teichholtz LE, Kreulen T, Herman MV, Gorlin R (1976) Problems in echocardiographic volume determination: echocardiographic-angiographic correlations in the presence or absence of asynergy. Am J Cardiol 37:7-11

Thuesen L, Christiansen JS, Mogensen CE, Henningsen P (1988) Cardiac hyperfunction in insulin-dependent diabetic patients developing microvascular complications. Diabetes $37: 851-856$

Dr. G. Nyberg

Department of Nephrology

Sahlgrenska Hospital

S-413 45 Gothenburg

Sweden 